\title{
E-GRIEF: IMPRESSION MANAGEMENT IN VIRTUAL GRIEF OF NEW MEDIA
}

\author{
Rulli Nasrullah \\ Faculty of Da'wa and Communication Studies \\ UIN Syarif Hidayatullah, Jakarta, Indonesia \\ (kangarul@gmail.com)
}

\begin{abstract}
Tradition or cultural expression of grief can be shown through one's presence, and this emotion is submitted directly to the family of the deceased. The emergence of new media, however, such as computers and the Internet provide a new direction in relation and human interaction. New media tools allow anyone to construct impressions of their condolences virtually. Through mediated computer communication analysis methods, the author reveals the characteristic of impressions shown by the audiences about a news of someone's death. The result of the study also shows that the virtual figure of the dead is still "considered" alive, though it is just a collection of archives and data from his/her virtual identity. The visitors who have emotional intimacy could still send messages and communicate with the deceased as if he were there in front of them.
\end{abstract}

Keywords: New Media, Impression Management, Grief, Facebook, Interaction.

\section{Introduction}

Once, I opened the social network site, Facebook; I was shocked after finding a picture of an old friend of mine who passed away. At that time, I did not know for whom were the expression of condolences were, apart from knowing the deceased during his lifetime living in different provinces and islands, I was also not very familiar with his family, specifically on having their personal contact info. Because of the feeling of uneasiness in sending a short message, I 
preferred conveying my condolences through another friend who is related and close to the family.

In the beginning, I was thinking that his Facebook page would be stopped from making interactions. This assumption is of course not unreasonable, besides the account owner has died, it was assumed to be an artefact unless other people knew the account's password which can both open or erase it. One or two months later, I open the account. To my amazement, I found the page full of "virtual conversation" between friends and account owner. The reason why I underlined these words is because the conversations seem to represent that the account owner can read the messages. Not only one or two, but there were more than eighty messages.

In the context of characteristics of new media, Gane and Beer (2008:71) provide a review of one of the characteristics of the new media which is an archive or as storage (archive). In new media, the archive must be understood regarding communications as technologies that change the way in generating, accessing, and in putting the information itself. It is clearly different from the archive that long had been understood as a set of documents containing certain information stored in a place-cupboard, room or warehouse - and it can only be accessed by certain people.

Also, in the perspective of new media, an archive does not only consist of text but photos, movies, and sounds. New media also allows one to make changes to stored files. As described by Appadurai (2003:17), at least two changes of the archive by the advent of communication technology; 1) the ability of Internet users to access any file and make changes to it and 2) the file becomes more developed, i.e., 'the nature and distributions of its users'. Archive, in this case, is not only seen as just certain official documents but the internet network, information distribution and mediation between man and machine which becomes a kind of data storage.

Meyrowitz (1995: 51) asserted that the recent study focuses on communication which is no longer just the message or content, but it should have penetrated on the development of communication technology to which it is attached, and it becomes a part of people's life (see Rosilnrunti, 2005). This statement is reinforced by David Holmes (2005:2), that in fact, people are now daily in touch with technology and now in an information society. Characteristic of the information society is not only in touch with information technology as such but also the use of communication technologies to diverse needs. Even CITs (Communication and Information Technologies) become phenomenal and at a certain level, change the way of people's view of 'object'; 
which ultimately brings a change of 'flavour' of the object as well as the relationship built.

The relationship of inter-individuals (entities) in the era of new media is no longer dominated by the physical or 'interface', but it is represented by the device or 'terminal' of communication technologies such as technological devices that we usually find in daily life. Even in the development of the cyber world today, the presence of the individual as an object can be represented by animation (avatar) by the wishes of the individual; on the internet, people can be anyone they want. These phenomena have been studied by Turkle (2011) that describes how technology has become an integral part of individual relationships as altogether arising problems, one of them is a bond coming from the relationship itself. Communication technology has the meaning of time and the reach in the relationship of inter-individual by using a new way of communication that is information technology. This is the reason the internet is the cornerstone of the global interaction technology development in the last decade of the 20th century that change the scope and the nature of the medium of communication, and culture or the culture of the communication process itself (Nasrullah, 2012b: 23-26; Thiruchelvam, 2011).

Center of reality and theoretical study above is a page in new media, Facebook, basically a storage archive of self-identity. However, in contrast to the meaning in the real world, archive here seems to be a substitute of living figure, although the fact shows that the account owner has no access to the account, as what happened to an old friend of mine who died. The main problem here is the rise of interaction built by someone else in the accounts. Although I am sure that they know it is impossible to communicate with the owner of the account, in fact, they still try to send the grief disclosure through virtual conversations. What imagination do these phenomena emerge?

\section{Problem Statement}

This paper begin from a question of "how is the construction of impression management in the expression of grief in the new media?" Focus of the problems are described through several questions, which are 1) the impression of brotherhood among Muslims, 2) the impression of intimacy, 3) exemplary impression, and 4) the impression as if he (the dead one) is alive. 


\section{The Objectives and Contributions of Study}

Although this research is relatively new, it is said to be unique because of the involvement of new media. This research suggests that there is a relation that exists between people, not only in the context of face-to-face but also in this new media, Facebook, which represents the relationship and communication between the communicant and communicator. In this study, communications are the expression of presented grief, basically, a new reality that will inevitably be faced as distinct phenomena compared to what happens in the real world; although it must be considered that in certain conditions. This phenomenon reduces inter-entity emotional bond. It becomes a challenge and prediction of how the technology will represent the relationship between the human being. It is also a stepping stone to see how Islamic laws address humanitarian issues later on self-disclosure in the new media, gossip (ghibah) through social media which involves the distribution of information from matters of personal privacy (the oikos) in public spaces (the eclesia) (see Bauman, 2000). It is a meeting between the private and public (the agora), which Castell stated' new media age regarding a shift from close-knit communal forms to mecentred networks' (Gane and Beer, 2008:78).

\section{Study of Literature and Theoretical Framework}

Self-impression and relationships of virtual inter-entity in cyber world are the phenomena that occur in interpersonal relationships that were originally revealed by many studies in the fields of communication, sociology, anthropology, to psychology. Marshal Mc Luhan, Wilbur Schramm, Stuart Hall, George Herbert Mead, Michel Foucault, Gilles Deleuze and Felix Guattari, Jean Baudrillard, Paul Virilio, etc. are some of the figures who provide a basis for approaching this phenomenon in the cyber world. Furthermore, the author finds that new media allows people to manipulate the identity and representation of himself (Jordan, 1999; Wood and Smith, 2005). It makes reliance on technology in establishing a friendship, but the fabric is a vacuum at the same time alienating the individual (Turkle, 2011, Idris \& Ghani, 2012; Ellison, Lampe, \& Steinfield, 2007). It creates the threat of virtual terrorism through the relationship that exists in new media (Nasrullah, 2012a). The openness in the virtual world and its relation to the creation of relationships between individuals (Mazer et.all., 2007). The text as the only means of communication on the Internet (Turing, in Polkosky 1950:442, 2008:40) and its effect on social relationships between individuals in 
cyberspace (Witte and Susan, 2010), and empathy in online communities (Ariani, 2011).

The concept of impression used by the author in this paper is a concept started from the impression management of appearance or self-performance known by Erving Goffman. Through his magnum opus, Presentation of Self in Everyday Life published in 1959, Goffman gives a theory of dramaturgy as a representation of individuals' performance in a social environment not much different from what happen in a stage show in which the actors play their characters by doing construction by the given role. Even tragically Goffman states that self-does not belong to the individual himself, but rather a kind of 'the product of the dramatic interaction between the audience and the actors with dramatic effects rose ... from the presented scenario (Goffman, 159:253; Ritzer and Goodman, 2004:399).

Goffman also offers what he describes as 'impression management' which means the actor hopes that the self-understanding obtains role they play. It is by the wishes of the audience and hopes that the audience can define and voluntarily accept the wishes of the actor, that there are actor's efforts to keep the audience impressions (Ritzer and Goodman, 2004:400). However, it is often for the actors to hide things to keep the impression. This is what Goffman called 'front stage' and 'back-stage'. The backstage is the actor's true identity, and the front stage is a stage to show his best performance and hide the reality.

The actor often presents an ideal character on stage so that they will hide something not known by the audience (Ritzer and Goodman, 2004:400-401). The reasons are: first, the actor may want to hide a secret pleasure that has become a habit before the show begins or in the past, that do not match their performances, such as the liquor habit. Second, the actor may want to hide the mistakes they did in preparation for the show as well as the steps they have taken to correct these errors such as a taxi driver who withhold information to the passengers that he had taken the wrong lane. Third, the actor may assume that he only needs to show and hide the final product of the production process. Fourth, the actor may have to hide the 'dirty work' from the audience in the manufacture of final product, in which different viewpoints job are 'not physically clean, semi-legal, violent, and from other degrading treatment' (Goffman, 1959:44). Fifth, at certain performances, the actor may have to let the falling of other standards, for example, an actor may be hiding insult, scorn, or humiliation during the show until the show are finished.

In this impression management, Goffman underlined that the capacity of giving the impression to the audience essentially involves what is called a 
"sign activity", i.e., 1) the expression that he gives, and 2) the expression that he gives off (Goffman, 1959: 2). In the first field, the impression will be generated through verbal symbols or replacing it with something familiar with him or the audience against these symbols; constituting the traditional view of communication and direction. The second one involves a diverse field of individual action as an addition to the role being played which by those, actions messages will be easily understood by the audience.

\section{Methodology}

Cyberspace on the internet puts the text as a representation of a person's identity. Although it is presented by the text and the text may not contain the overflowing meaning (Jordan, 1999), but the move of the text author becomes the gate to explore how impressions are awakened by online and offline. The author makes four levels of analysis to fulfil the data collection requirement, called Analysis of Computer-Mediated Communication. It is author's exploration from analysis of relation in cyberspace that puts cyberspace (web sphere) as the unit of analysis known by December (1996) altogether with approaches to the reality of Internet usage categories developed by Bell (2001). The media space, archive media, media object, and experiential stories (Nasrullah, 2012).

Media space and media objects are the focus of the research in the virtual space or online, while media experience level is multilevel analysis to see how the reality of the real (offline) causes or affect an online reality. In the media room, this level reveals the structure of citizen journalism media, such as how to make accounts, publishing procedures of contents, and graphical aspects of display media. To obtain data, on this level, the writer uses observation techniques; in practice, the author does not only position himself as an observer but also directly involving, for example, in having an account and a personal page on the media citizen journalism. Levels of archive media are used to see a content - text and meaning contained in it published through the media citizen journalism. At this level, the technique used is the study documentation.

The next level is the level of media objects. At this level, the media object is a specific unit because the author sees how activities and interactions of users (audiences) and inter-users are going. In this level, the author uses data collection techniques as the ethnographical practice of communication. Here the author focuses on the field research, making observations, asking questions of the subjects, participating in community activities or conducting tests on 
how the local people's perception or intuition (Saville-Troike.2003:3). At the level of experiential stories, this level connects the virtual world and the real world. It is especially to see and reveal how the underlying motives for users utilise and publish content in citizen journalism and the media to see what is going on in the network (online) that is also influencing the real world (offline). The data obtained through observation, study of documents or subsequent interviews are analysed descriptively through the case study method.

\section{Table1}

Object and analysis of mediated Communication Analyses

\begin{tabular}{|l|l|}
\hline \multicolumn{1}{|c|}{ Level } & \multicolumn{1}{c|}{ Objek } \\
\hline Media space & $\begin{array}{l}\text { the structure of media and } \\
\text { performance devices }\end{array}$ \\
\hline media archive & $\begin{array}{l}\text { content, text/graphic aspect } \\
\text { of meaning }\end{array}$ \\
\hline media object & $\begin{array}{l}\text { Users and } \\
\text { interactions/activities of } \\
\text { users }\end{array}$ \\
\hline experiential stories & $\begin{array}{l}\text { motives, effects, utilities or } \\
\text { realities related to online } \\
\text { and offline }\end{array}$ \\
\hline
\end{tabular}

\section{Discussions and Findings}

At the level of the media device, the Facebook facility allows individuals to construct their impression management in expressing grief altogether as selfrepresentation (impression) to the owner's account. The provided "wall" of Facebook allows users to express themselves, inform their activities, and show what they think anytime. "Wall" also allows the users to give comments or reactions among others' activities. Also, the "wall" is provided as a stage where an actor Facebook account's owner displays his role of self-performance, space for constructing identity-in Goffman's view as a fulfilment of the appreciation of other users. 


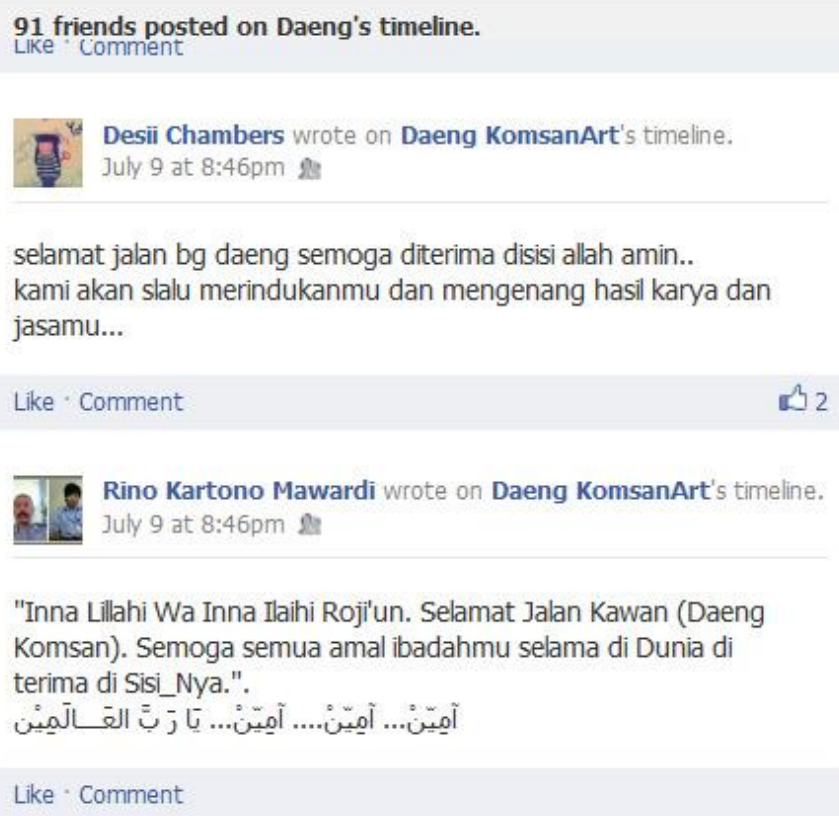

Rino Kartono Mawardi wrote on Daeng KomsanArt's timeline. July 9 at $8: 46 \mathrm{pm}$ \&

"Inna Lillahi Wa Inna Ilaihi Roji'un. Selamat Jalan Kawan (Daeng Komsan). Semoga semua amal ibadahmu selama di Dunia di terima di Sisi_Nya.".

"Farewell brother Daeng, may you rest in peace in the mercy of Allah, we will always miss you and remember all your kindness and love..."

"Innalillahi Wa Inna Ilaihi Roji'un. Farewell mate (Bang Daeng). May all your worldly kindness be placed on Allah's side."

\section{Figure 1}

Facebook wall devices that allow visitor to leave message Source: http://www.facebook.com/daeng.komsanart?fref=ts accessed at October 2 $2^{\text {nd }}, 2012$

The level of media documents reveals the presence of the wall as a gateway to see the impression text imagined by visitors. Therefore through the Facebook wall, visitors can write and read grief messages left by other visitors. Also, at this level, the author finds how the impression management is built. The first finding explains that the comment column can be used to show the impression among Moslems in the sense of showing sympathy and condolences (see comments Rino Kartono Mawardi in Figure 1).

The second impression which emerges in virtual grief is the impression of intimacy that visitors do not just write the text as such grief, but also add or construct a message that indicates how close the relationship between visitors and the deceased. 
Muhammad Bagya Mutamar wrote on Daeng KomsanArt's timeline.

July 12 at 7:13am 8

okelah bang..ntar gw nyusul..santai aja dulu di sana..kita kumpul lg kok..nanti..

Like · Comment

Annyong Hasse Yo wrote on Daeng KomsanArt's timeline.

July 10 at $4: 38 \mathrm{pm}$ is

selamat jalan bang daeng... saye rindu' same abang.. :'(

Like · Comment

"Okay brother, be patient... enjoy there.. we'll be together.. later."

“Farewell brother Daeng, I miss you :.."

\section{Figure 2}

Close impression built by the visitors

Source: http://www.facebook.com/daeng.komsanart?fref=ts accessed at October 2nd, 2012

Furthermore, the impression encountered is an exemplary impression. This impression arises from the construction of the comments which indicate that the deceased hangs a good manner and kindly behaves during his lifetime so that it makes a deep impression for the commenter. This context shows that the comments and the grief situation are not only used in delivering a virtual expression of grief, but also as a media for the expressing an endorsement (Figure 3). This means that visitors use the media to convey memories, statements, testimony until the memory of the deceased during the lifetime interaction. 
Rizal Daeng wrote on Daeng KomsanArt's timeline.

July 9 at 9:26pm is

Kali pertama sy mengenalmu di sbh ruang kecil di sudut STAIN Ptk. Tempat itu mungil, jauh dr kebesaran nama Komunitas Santri. Di situ kamu letakkan fondamen dasar berteater, mangasah kegilaan kreativitas seni, walau perut hanya diisi daun ubi rebus. 12 thn kemudian, amat jarang kita berjumpa. Begitu mendengar kepergianmu, saya tersadar betapa besar kehilangan telah terjadi. Selamat jalan kawan. Allah menyayangimu.

Like ' Comment

Chyndee Lu wrote on Daeng KomsanArt's timeline.

July 10 at 5:59am \&

Ternyata kereta kencana lebih dulu menjemput mu Henry.. lbh sayang pd mu, istirhat lah dgn tnang..krna ssungguhnya abg sdh bnr2 smbuh dr rs skit. Kenangn,ilmu,ajarn,masukan,kri tik,psan,semua itu akn jd bkal plirn buat kami Selamat jlan Henry,simt jln kura2,simt jln b.daeng...

"The first time I met you with a side of the small room in STAIN's corner, the tiny place, far from the great name of Moslem community. There you teach me

a theatre fundamentally, crazily explore art creativity, though we just ate boiled cassava. After 12 years we were rarely meet each other. Hearing the news of your grief, I realise how you are so mean to me. Goodbye, mate. Allah loves you."

“Apparently, the Kencana carriage has come to you, Henry... Allah loves you more. Rest in peace because you are now truly free from your sufferings. Memories, knowledge, suggestions, criticisms, messages will be a meaningful lesson for us. Goodbye Henry, goodbye turtle, goodbye Daeng..." Exemplary impression

\section{Figure 3}

Source: http://www.facebook.com/daeng.komsanart?fref=ts accessed at October $2^{\text {nd }}, 2012$ 
The interesting thing is that the author also found out that this level of comment space is also used by the users to talk virtually. The message sent is not intended as an expression of grief but more as if they were talking or making conversation with the deceased (Figure 4). It means that the phrases or text left in the Facebook comments explicitly or implicitly indicate that the visitors have simply left him a message even though they knew that the receiver is already deceased. It shows that there is a phenomenon or the own imagination that account owner as if to consider that it is still alive and can read the post.

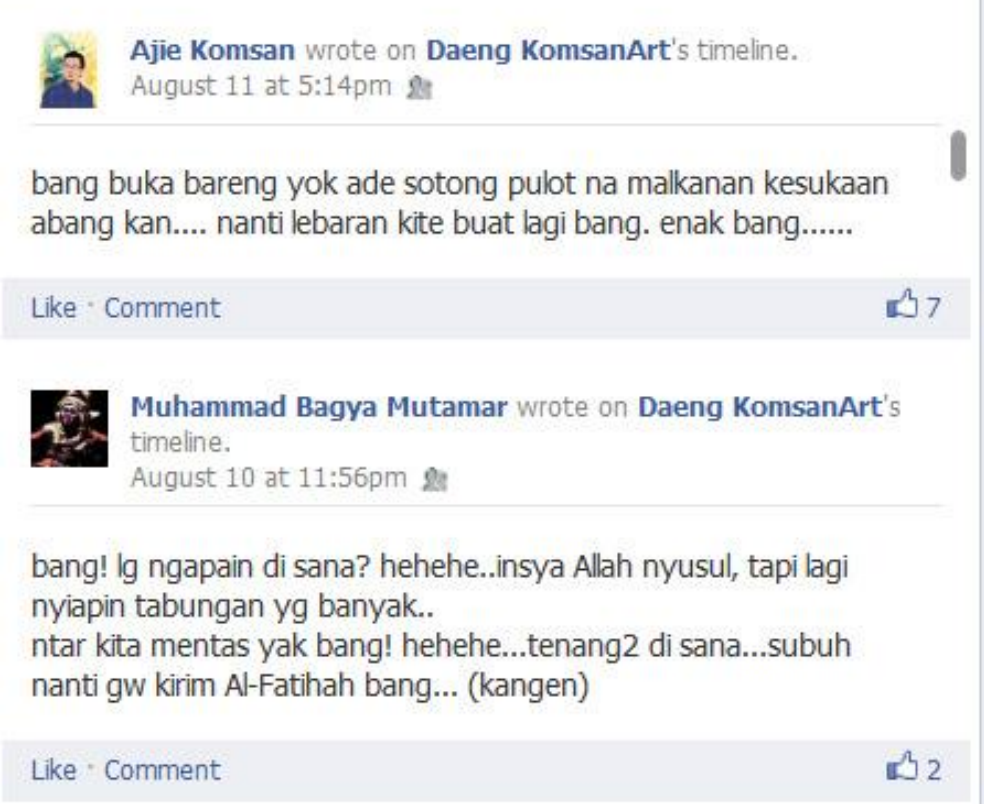

"Brother, let's get breakfasting together. I have sotong pulot (kind of fish), your favourite food, isn't?... let's make it together on next day of Eid. It's delicious, brother."

“Bro, what are you doing there? Hehe... InsyaAllah I'll come but still I have to make better preparation.

We'll play a theatre there again! Hehehe, be calm, I'll send you Al-Fatihah on subuh bro (missing you)"

\section{Figure 4}

Treating as he is still alive

Source: http://www.facebook.com/daeng.komsanart?fref=ts accessed at

October 2nd, 2012 
From the description above, the author concludes that the virtual expression of grief can essentially cause different impression and construction. This context allows the author to use object media to illustrate the user activity (Facebooker) in the virtual space. There are at least two things that show how new technologies and social media change culture expressions of grief: first, there is a demonstrated fact that even though the account owner is physically dead but other users still think that he is still alive virtually. This fact is supported by the appearance of the conversation ensued in the comments space (see Figure 4). In the search, the author also finds a virtual figure still alive in the eyes of other users; at least it is shown in birthday comments as shown below:

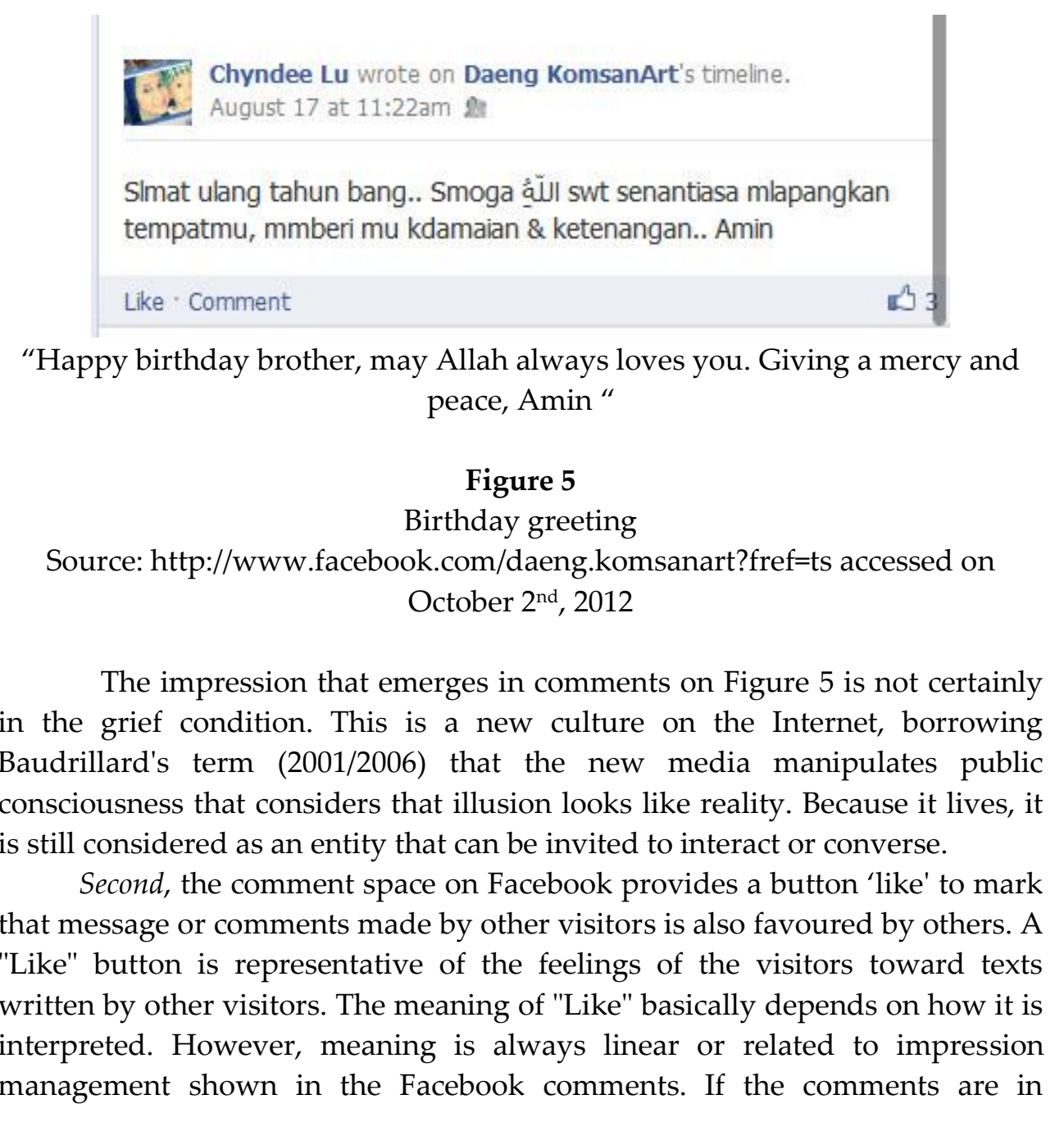


mourning, the meaning of "Like" is also grieving. Furthermore, if the status of being overwhelmed, then "Like" given by friends supports a sense of what is going on. This proves that a new way of virtual grief expression gets the attention of other users.

While in the level of experiential stories, the author finds that impression management construction built by the users of social media is initially a process of sending a virtual grief. It is for the deceased whether reasons are matters of geographical location, not able to visit the family to show his grief in time and entertain those who left (sympathy). Also, the Facebook devices can be used to reply expression as a statement from the family or relatives of the deceased.

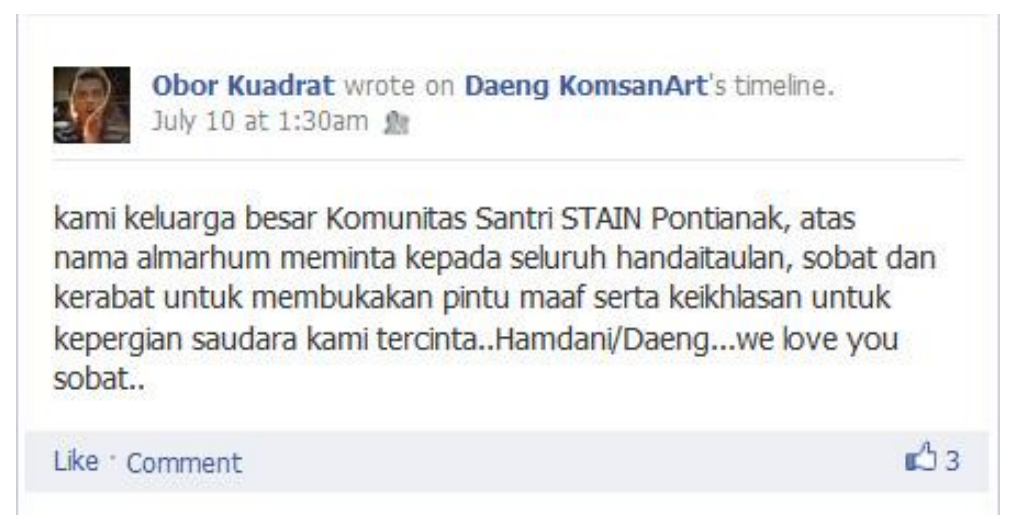

"We, the big family of Moslem Community of STAIN Pontianak, stand for the name of the deceased begging apologies to all relatives, and friend for the death of my beloved brother Hamdani/Daeng. We love you mate."

\section{Figure 6}

The statement stands for the dead family.

Source: http://www.facebook.com/daeng.komsanart?fref=ts accessed at October $2^{\text {nd }}, 2012$

\section{Conclusion}

This reality is presented by advances in technology. In spite of offline, the expression of grief can be delivered in the real world, the virtual (online) social media facilitates public to participate in a virtual to express sorrow or sorry for the deceased and his family. It means that text is the only marker in this virtual mourning and text can also be constructed by anyone to show them the impression of someone's death news on Facebook. Regardless of the motives 
behind the construction of virtual grief expression, these phenomena connect realities to virtual reality, such as no need to send flowers, greeting cards or visiting the family of the deceased to show sympathy. These all are provided by Facebook.

These phenomena are said to be one of the characteristics of the new media. It is a simulation or hyperreality: a term taken from Jean Baudrillard's theory in his Simulations and Simulacra (1994). Each will eventually be mediated; that he called as 'ecstasy of communication', as it 'lives' on the computer screen or even a part thereof living life in a circumstance of 'hyperreality' that puts individuals between the real and the virtual, reality and illusion. This term is made from four stages of the process. Firs, the sign -a presentation of reality, second; Mark distorts reality, third; the reality is blurred and even disappear, the even sign is no longer a representation of representation itself, and fourth; the sign is no longer associated with realityimage has become a substitution for reality itself. Here is what happens according to Bell in cyberspace, where the simulation takes place and the development of communication technology altogether with the emergence of new media that have increasingly distance individual from reality, creating a new world that is called a virtual world.

Media, Baudrillard's concept, is not a reflection of reality but it has become a reality of its own. This is what Baudrillard calls a hyper reality, where media is no longer showing the reality of its own but it is becoming a reality even what things in the media are more tangible (real) from reality itself (Ritzer and Goodman, 2004: 678). The reality of media is the result of the simulation process, in which representation in the media has been produced and reproduced by the media itself. It becomes its reality; sometimes what a thing represents is different or even opposite of signs or objects themselves. The reality in television, for example, is a new reality that Baudrillard states as 'simulacra', which does not only explain how the mark is represented but also involve social relationships and power/social influence (Baudrillard, 1993:52 in Gane and Beer, 2008: 104). How the simulation happens is explained by Baudrillard that in industrial societies today, production is no longer producing a doubling of reality but it has become a mass production of the same reality that sometimes it is not identical to what is represented. Furthermore, the industrial era is no longer reproducing and carrying out mass production of the original object, but it has produced an identical object which the origin object does not longer exist essentially or the loss of characteristics of the produced object. The third phase of simulacra of Baudrillard is mass production of objects which are not identical with the 
origin. There are no signs, traits, characteristics and even any equation of the object produced. According to Baudrillard, due to technology and media that have the power not only to produce but also reproduce the signs and objects.

Finally, in the process of simulacra, the resulted mark has become its reality. The sign cannot be sorted to find common ground between realities or signs originally produced. The substance of the fundamental reality has gone; reality produced by technology for Baudrillard has become an entirely new reality. In the relation with the new media, technology has brought a culture that distinguishes between the real and the virtual. Humans, as users, have been represented by hardware and software on a computer network and traffic of information.

It is apparently the "miracle" of new media that represents a virtual expression of grief through technology ignoring the need of face to face deal.

\section{References}

Appadurai, Arjun. (2003) "Archive and Inspiration", in Joke Brouwer and Arjen Mulder (eds.). Information is Alive. Rotterdam: V2/NAi.

Ariani, Prida. (2011) Empati dalam Komunitas Kesehatan Online on proceeding Conference of National Communication. Jakarta: Universitas Indonesia, pp.122-139.

Baudrillard, Jean. (2001/2006) The Precession of Simulacra in Durham, Meenakshi Gigi and Kellner, Douglas M. (ed.). Media and Cultural Studies, Keywords. Malden, MA: Blackwell Publishing.

Bell, David. (2001) An Introduction to Cybercultures. London and New York: Routledge,

December, John. (1996) "Units of Analysis for Internet Communication", in Journal of Communication 46(1) Winter. 0021-9916/96, $<$ http://jcmc.indiana.edu/vol1/ issue4/december.html $>$ (accessed on $4^{\text {th }}$ August 2012).

Ellison, N., Lampe, C. \& Steinfield, C. (2007). 'The Benefits of Facebook "Friends": Social Capital and College Students' Use of Online Social Network Sites, Journal of Computer-Mediated Communication.Vol.12, pp1148-1168

Gane, Nicholas and Beer, David. (2008) New Media: The Key Concepts. Oxford \& New York: Berg. 
Goffman, Erving. (1956/1990) The Presentation of Self in Everyday Life. Harmondsworth: Penguin.

Hine, Christine. (2000) Virtual Ethnography. London, Thousand Oaks, New Dehli: SAGE Publication.

Holmes, David. (2005) Communication Theory: Media, Technology and Society. London, Thousand Oaks, New Dehli: SAGE Publications.

Idris, Hayati. \& Ghani, Rozina Abdul (2012). Construction of Knowledge on Facebook, Journal 3L: The Southeast Asian Journal of English Language Studies.Vol.18 (3), pp 61-72-1168.

Meyrowitz, J. (1995) Medium Theory, in D. Crowley and D. Mitchell (eds), Communication Theory Today. Cambridge: Polity.

Nasrullah, Rulli. (2012a) POLITIK SIBER DAN TERORISME VIRTUAL. Jurnal Esensia Vol.XIII No.1, pp.109-222.

Nasrullah, Rulli. (2012b) Komunikasi Antarbudaya di Era Budaya Siber. Jakarta: Kencana.

Ritzer, George dan Goodman, Douglas J. (2008) Teori Sosiologi, Dari Teori sociology Klasik sampai Perkembangan Mutakhir Teori Sosial Postmodern. Yogyakarta: Kreasi Wacana.

Rosilnrunti, Z. (2005). Information Technology (IT) as an Innovative Tool in Tourism Development. JATI (Journal of Southeast Asian Studies). 10(1), 109-126. Retrieved from http://umrefjournal.um.edu.my/filebank/published_article/3650/109126 - Rosilawati-Information Technology(IT) - JATI 10, 2005.PDF.

Saville-Troike, Muriel. (2003) The Ethnography of Communication, New York: Blackwell Publishing.

Thiruchelvam, C. a/p C. (2011). The Evolving Media Culture that is Transforming and Being. JATI (Journal of Southeast Asian Studies). Volume 16, 2011. 77-95. Retrieved from http://umrefjournal.um.edu.my/filebank/published_article/3164/077095 Cheryl Chelvam-media culture-JATI 16, 2011- new.pdf

Turkle, Sherry. (2011) Alone Together, Why We Expect More from Technology and Less from Each Other. Newyork: Basic Books.

Witte, James C. and Susan E. Mannon. (2010) The Internet and Social Inequalities. New York: Routledge.

Wood, Andrew F. and Smith, Matthew J. (2005) Online Communication: Linking Technology, Identity, and Culture. Mahwah, New Jersey: Lawrence Erlbaum Associates. 